\title{
Pengaruh Manajemen Laba Terhadap Nilai Perusahaan pada Industri Manufaktur yang Terdaftar di Bursa Efek Indonesia Periode 2015-2017
}

\author{
Hana Tamara Putri \\ Fakultas Ekonomi, Universitas Batanghari Jambi, Indonesia
}

\begin{abstract}
The purpose of this research is to analyze the effect of earnings management measured by real-based earnings management on company value that mesured by price to book value ratio. This research was conducted in some manufacturing companies listed on the Indonesia Stock exchange for period of 2015-2017. The sample was selected as many as 34 companies. The method of analysis uses associate descriptive analysis with simply linier regression analysis tools by testing classical assumption, testing hypotheses and coefficient of determination. Based on the results of the study found that earnings management as measured by real based earnings management affect the company's value.
\end{abstract}

Keywords: earnings management, company value, real based management.

\section{PENDAHULUAN}

Manajemen Laba didefinisikan sebagai upaya manajer perusahaan untuk mengintervensi atau memengaruhi informasi dalam laporan keuangan dengan tujuan untuk mempengaruhi stakeholder yang ingin mengetahui kinerja dan kondisi perusahaan. Manajemen laba dapat meningkatkan kepercayaan pemegang saham terhadap manajer. Manajemen laba berhubungan erat dengan tingkat perolehan laba atau prestasi usaha suatu organisasi, hal ini karena tingkat keuntungan atau laba dikaitkan dengan prestasi manajemen dan juga besar kecilnya bonus yang akan diterima oleh manajer. Timbulnya manajemen laba dapat dijelaskan dengan teori agensi. Sebagai agen, manajer secara moral bertanggung jawab untuk mengoptimalkan keuntungan para pemilik (principal) dan sebagai imbalannya akan memperoleh kompensasi sesuai dengan kontrak. Dengan demikian terdapat dua kepentingan yang berbeda didalam perusahaan dimana masing-masing pihak berusaha untuk mencapai atau mempertahankan tingkat kemakmuran yang dikehendaki Manajer sebagai pengelola perusahaan lebih banyak mengetahui informasi internal dan prospek perusahaan di masa yang akan datang dibandingkan pemilik (pemegang saham). Manajer berkewajiban memberikan sinyal mengenai kondisi perusahaan kepada pemilik. Sinyal yang diberikan dapat dilakukan melalui pengungkapan informasi akuntansi seperti laporan keuangan. (Adisetiawan dan Surono, 2016)

Laporan keuangan tersebut penting bagi para pengguna eksternal terutama sekali karena kelompok ini berada dalam kondisi yang paling besar ketidakpastiannya. Ketidakseimbangan penguasaan informasi akan memicu munculnya suatu kondisi yang disebut sebagai asimetri informasi (information asymmetry). Asimetri antara manajemen (agent) dengan pemilik (principal) dapat memberikan kesempatan kepada manajer untuk melakukan manajemen laba (earnings management) dalam rangka menyesatkan Investor (pemegang saham) mengenai kinerja ekonomi perusahaan menunjukkan adanya hubungan positif antara asimetri informasi dengan manajemen laba. Ada beberapa cara yang dilakukan oleh manajemen dalam melakukan manajemen laba, diantaranya adalah melalui manipulasi akrual (manajemen laba akrual) dan manipulasi aktivitas real (manajemenlaba real). Perkembangan. penelitian empiris mengenai manajemen laba telah menemukan bahwa manajer telah bergeser dari manajemen laba akrual ke manajemen laba real. Gunny (2005), Zang (2006), serta Cohen dan Zarowin (2008) menemukan bahwa manajer sudah bergeser menjauh dari manajemen laba akrual menuju ke manajemen laba real setelah periode Sarbanes-Oxley Aet (SOX).

Pergeseran dari manajemen laba akrual ke manajemen laba real ini disebabkan karena: pertama, manipulasi akrual kemungkinan besar akan menarik perhatian auditor atau regulatory scrutiny dibanding dengan keputusan - keputusan real, seperti yang dihubungkan dengan penetapan harga dan produksi. Kedua, mengandalkan pada manipulasi akrual saja membawa risiko. Hal ini disebabkan karena jika realisasi akhir tahun yang defisit antara laba yang tidak dimanipulasi dengan target laba yang diinginkan melebihi jumlah yang dimungkinkan untuk memanipulasi akrual setelah akhir periode maka laba yang dilaporkan akan turun 
dari target sehingga strategi berbasis akrual yang digunakan menjadi lemah. Jika target laba yang diinginkan tidak tercapai maka manajer dianggap tidak mempunyai kinerja yang baik sehingga kesempatan mendapatkan kompensasi akan hilang atau bahkan bisa berujung pada pemecatan manajer. Oleh karena itu, melakukan manipulasi melalui aktivitas real. merupakan jalan aman untuk mencapai target laba karena bisa dilakukan disepanjang periode operasi perusahaan sehingga kemungkinan laba kurang dari target bisa ditiadakan. (Adisetiawan, 2011)

Selain memperhatikan Laba Perusahaan Investor menggunakan Laporan Keuangan untuk melihat Nilai Perusahaan. Nilai perusahaan dapat diukur dengan menggunakan harga saham menggunakan rasio yang disebut rasio penilaian. Rasio Penilaian adalah suatu rasio yang terkait dengan penilaian kinerja saham perusahaan yang telah diperdagangkan di pasar modal (go public). Rasio penilaian memberikan informasi seberapa besar masyarakat menghargai perusahaan, sehingga masyarakat tertarik untuk membeli saham dengan harga yang lebih tinggi dibanding nilai bukunya. Salah satu rasio penilaian yang sering dipakai oleh investor adalah PBV (Price to Book Value). Price to Book Value (PBV) adalah rasio yang menunjukkan apakah harga saham yang diperdagangkan overvalued (di atas) atau undervalued (di bawah) nilai buku saham tersebut. Price to Book Value (PBV) menggambarkan seberapa besar pasar menghargai nilai buku saham suatu perusahaan. Makin tinggi rasio ini, berarti pasar percaya akan prospek perusahaan tersebut. PBV juga menunjukkan seberapa jauh suatu perusahaan mampu menciptakan nilai perusahaan yang relatif terhadap jumlah modal yang diinvestasikan. Untuk perusahaan-perusahaan yang berjalan dengan baik, umumnya rasio ini mencapai diatas satu, yang menunjukkan bahwa nilai pasar saham lebih besar dari nilai bukunya. Semakin besar rasio PBV semakin tinggi perusahaan dinilai oleh para pemodal relatif dibandingkan dengan dana yang telah ditanamkan di perusahaan.

Pada akhir triwulan III 2017 Perusahaan-Perusahaan yang tergabung dalam Industri Manufaktur menunjukkan kinerja yang sangat bagus beberapa subsektor menunjukkan kinerja di atas pertumbuhan ekonomi. Misalnya, industri logam dasar sebesar 10,60\%, industri makanan dan minuman 9,49\%, serta industri alat transportasi 5,63\%. Pada periode 2015-2017 telah berproduksi industri smelter terintegrasi dengan produk turunannya berupa stainless steel yang memiliki kapasitas dua juta ton per tahun. Jumlah ini naik dibanding dengan tahun 2014 yang hanya mencapai 65.000 ton produk setengah jadi berupa feronikel dan nickel matte. Penyerapan total tenaga kerja yang terserap di sektor manufaktur pada 2017 sebanyak 17,01 juta orang, naik dibandingkan tahun 2016 yang mencapai 15,54 juta orang. Capaian ini mendorong pengurangan tingkat pengangguran dan kemiskinan di Indonesia yang cukup signifikan. Sektor-sektor yang menyerap tenaga kerja cukup banyak, antara lain industri makanan dan minuman lebih dari 3,3 juta orang, industri otomotif sekitar 3 juta orang, industri tekstil dan produk tekstil sebanyak 2,73 juta, serta industri furnitur berbahan baku kayu dan rotan nasional untuk tenaga kerja langsung dan tidak langsung mencapai 2,5 juta orang. Tujuan Penelitian ini adalah untuk mengetahui pengaruh Manajemen Laba terhadap Nilai Perusahaan pada Industri Manufaktur yang terdaftar pada Bursa Efek Indonesia Periode 2015-2017.

\section{Tinjauan Pustaka \\ Manajemen Laba Riil}

Secara umum manajemen laba merupakan salah satu faktor yang dapat mengurangi kredibilitas laporan keuangan. Healy dan Wahlen (1999) menyatakan manajemen laba terjadi ketika para manajer menggunakan pertimbangan dalam pelaporan keuangan dan penyusunan transaksi untuk merubah laporan keuangan yang menyesatkan pemegang saham tentang kinerja ekonomik organisasi atau untuk mempengaruhi hasil sesuai dengan kontrak yang tergantung pada angka-angka akuntansi yang dilaporkan. Penelitian mengenai manajemen laba riil juga dilakukan Chen et al. (2008) menemukan bahwa terjadi penurunan nilai yang signifikan untuk perusahaan yang melakukan manajemen laba real yang menandakan bahwa pasar dapat menduga terjadinya manajemen laba real dengan melakukan pengamatan terhadap abnormal dalam operasi perusahaan setelah pengumuman laba kuartalan. Namun penelitiannya cuma memfokuskan manajemen laba real dengan cara pengurangan pengeluaran biaya riset dan pengembangan dan produksi yang berlebihan sehingga tidak menggambarkan dampak manajemen laba real secara menyeluruh terhadap nilai perusahaan.

Teknik untuk manipulasi aktivitas real adalah: 
a. Manipulasi penjualan

Manajer penjualan akan berusaha menaikkan penjualan selama perioda akuntansi dengan tujuan meningkatkan laba untuk memcapai target laba. Hal ini bisa dilakukan manajer dengan menambah penjualan atau mempercepat penjualan dari periode mendatang ke periode sekarang dengan cara menawarkan diskon-diskon yang menarik dan berani serta menawarkan jangka waktu kredit yang lebih lunak. Dengan melakukan pemberian diskon-diskon yang berani tahun ini akan meningkatkan volume menjualan sehingga mencapai target jangka pendek dan kinerjanya kelihatan baik serta manajer bisa memperoleh bonus. Tapi pemberian diskon ini akan membuat pelanggan berharap untuk memperoleh diskon-diskon yang sama dimasa yang akan datang, sehingga meningkatkan laba tahun sekarang namun mempunyai dampak negatif terhadap terhadap aliran kas masa depan.

b. Produksi secara berlebihan

Manajer perusahaan dapat meningkatkan laba dengan melakukan produksi besar-besaran. Produksi dalam skala besar menyebabkan biaya overhead tetap dibagi dengan jumlah unit barang yang besar mengakibatkan rata-rata kos per unit dan kos barang terjual menu run. Penurunan kos barang terjual tersebut .akan berdampak pada peningkatan margin operasi.

c. Pengurangan pengeluaran diskresioner

Pengeluaran diskresioner yang dapat dikurangi adalah beban iklan, penelitian dan pengembangan, beban umum penjualan dan administrasi. Mengurangi beban ini tanpa bpertimbangan yang cermat memang bisa meningkatkan laba perioda berjalan, dan dapat juga meningkatkan aliran kas periode sekarang, jika perusahaan secara umum membayar biaya seperti itu secara tunai tapi dapat berakibat buruk terhadap laba masa depannya. Oleh karena itu pengurangan pengeluaran diskresioner secara ektensif dari kondisi ekonomi normal merupakan tindakan manajemen laba.

\section{Nilai Perusahaan}

Fama (1978) dalam Wahyudi dan Pawestri (2006) menyatakan nilai perusahaan akan tercermin dari harga pasar sahamnya. Nilai perusahaan tercermin dalam nilai pasar dari suatu ekuitas perusahaan dan nilai pasar utang. Peluang investasi di masa mendatang juga akan mendorong kenaikan nilai perusahaan. Peluang investasi membutuhkan tambahan dana, sehingga keputusan perusahaan untuk menambah modal dalam bentuk saham baru dan atau utang akan meningkatkan nilai perusahaan. Fakta empiris di pasar modal Indonesia menunjukkan bahwa keputusan pendanaan, kebijakan deviden, keputusan investasi, pertumbuhan perusahaan, dan ukuran perusahaan memiliki pengaruh terhadap pergerakan nilai perusahan. Dapat dikatakan bahwa semakin tinggi harga ekuitas dan utang maka semakin tinggi nilai perusahaan, demikian juga sebaliknya. Tidak ada nilai perusahaan yang sama, setiap investor mempunyai cara pandang yang berbeda dalam merespon informasi-informasi terkait dengan kinerja perusahaan ataupun perubahan kondisi perekonomian. Banyak cara yang dapat digunakan untuk menilai perusahaan, salah satunya adalah Price to Book Value $(P B V)$. Price to Book Value (PBV) menggambarkan seberapa besar pasar menghargai nilai buku saham suatu perusahaan. Makin tinggi rasio ini, berarti pasar percaya akan prospek perusahaan tersebut. PBV juga menunjukkan seberapa jauh suatu perusahaan mampu menciptakan nilai perusahaan yang relatif terhadap jumlah modal yang diinvestasikan

\section{Operasional Variabel}

\begin{tabular}{|c|c|c|}
\hline Variabel & Proksi & Formula \\
\hline Manajemen & Manajemen Laba & $C F O_{t} / A_{t-1}=\alpha_{0}+\alpha_{1}\left(1 / A_{t-1}\right)+\beta_{1}\left(S_{t} / A_{t-1}\right)+\beta_{2}\left(\Delta S_{t} / A_{t-1}\right)+\varepsilon_{1}$ \\
\hline \multirow[t]{6}{*}{ Laba } & Riil berdasarkan & Ket: \\
\hline & model & $C F O_{t}=$ current operations pada perusahaan I dalam tahun $t$. \\
\hline & & $A_{t-1}=$ total Assets pada perusahaan I dalam tahun $t$. \\
\hline & & $S_{t}=$ sales pada perusahaan I dalam tahun $t .$. \\
\hline & & $\begin{array}{l}\Delta S_{t}=\text { sales pada perusahaan I dalam tahun t. dikurangi sales pada } \\
\text { tahun t-I. }\end{array}$ \\
\hline & & $\alpha=$ regression coefficient. $\varepsilon_{t}=$ error term in the period of.....? \\
\hline $\begin{array}{l}\text { Nilai } \\
\text { Perusahaan }\end{array}$ & $\begin{array}{l}\text { Price to Book Value } \\
(P B V)\end{array}$ & $P B V=$ Market Price per Share / Book Value per Share \\
\hline
\end{tabular}




\section{METODE PENELITIAN}

Penelitian ini menggunakan Data sekunder berupa laporan keuangan Industri Manufaktur yang telah dipublikasikan di Bursa Efek Indonesia periode 2015-2017. Sumber data diperoleh dari website resmi Bursa Efek Indonesia yaitu www.idx.co.id. Metode Pengumpulan Data dilakukan melalui riset pustaka atau library research yang terkait studi referensi dari sumber data pendukung. Adapun yang menjadi Populasi pada penelitian ini adalah Perusahaan-Perusahaan yang tergabung dalam Industri Manufaktur Periode 2015-2017 dan dengan menggunakan metode Purposive Sampling dengan sampel yang memenuhi kriteria pada penelitian ini yaitu yang memiliki ketersediaan data sehubungan dengan perhitungan formula variabel yang dibutuhkan terdapat 34 Perusahaan yang menjadi sampel penelitian.

Alat analisis data yang digunakan adalah Regresi Linier Sederhana dengan persamaan:

$\mathrm{Y}=\mathrm{a}+\mathrm{bX}+\mathrm{e}$

$\mathrm{Y}=$ Nilai Perusahaan, $\mathrm{a}=$ konstanta, $\mathrm{b}=$ Koefisien Variabel $\mathrm{X}, \mathrm{X}=$ manajemen laba riil dan $\mathrm{e}=$ error

\section{Uji Asumsi Klasik}

Prasyarat Metode Regresi Linier maka penelitian ini menggunakan Uji Asumsi Klasik berupa Uji Normalitas, Uji Multikolinearitas, Uji Autokorelasi dan Uji Heteroskedastisitas. Untuk menjawab Tujuan Penelitian menggunakan Uji Hipotesis Uji t dengan level signifikansi 95\% atau $\alpha(5 \%)$ dimana jika nilai signifikansi $\mathrm{t}<\alpha(5 \%)$ maka terdapat pengaruh yang signifikan.

\section{HASIL DAN PEMBAHASAN}

Berdasarkan Hasil Uji Asumsi Klasik, Data diketahui berdistribusi Normal, tidak terjadi gejala multikolinearitas, tidak terjadi Heteroskedastisitas dan tidak terdapat Autokorelasi. Diperoleh Hasil Persamaan Regresi Linier Sederhana yaitu :

Tabel 1

Koefisien

\begin{tabular}{|rl|r|r|r|}
\hline \multirow{2}{*}{ Model } & \multicolumn{2}{|c|}{ Unstandardized Coefficients } & \multicolumn{2}{c|}{ Standardized Coefficients } \\
\cline { 3 - 5 } & (Constant) & B & Std. Error & Beta \\
\hline \multirow{2}{*}{1} & MER & 2,747 &, 158 &, 395 \\
\hline
\end{tabular}

Sumber: data olahan

$\mathrm{Y}=2,747+0,369 \mathrm{X}$

Nilai konstanta sebesar 2,747 berarti bahwa jika nilai Manajemen Laba Riil bernilai 0, maka variabel Nilai Perusahaan bernilai 2,747.

Nilai koefisien regresi bernilai positif 0,369 berarti setiap peningkatan Manajemen Laba Riil sebesar satu satuan maka akan meningkatkan nilai perusahaan sebesar 0,369. Berdasarkan hasil perhitungan juga diperoleh nilai koefisien determinan yaitu:

Tabel 2

Summary

\begin{tabular}{|l|r|r|r|}
\hline Model & R & R Square & Adjusted R Square \\
\hline 1 & ,395 &, 156 & \\
\hline
\end{tabular}

Sumber: data olahan

Nilai koefisien Determinan $\left(\mathrm{R}^{2}\right)$ sebesar 0,156 atau sebesar 15,6\% menunjukkan bahwa pengaruh Manajemen Laba Riil terhadap Nilai Perusahaan hanya sebesar 15,6\% sedangkan sisanya 84,4\% dipengaruhi variabel lain yang tidak diteliti pada penelitian ini. Berdasarkan hasil uji hipotesis diperoleh nilai signifikansi sebesar 0,011 dimana nilai tersebut lebih kecil dari 0,05 $(0,011<0,05)$ artinya $\mathrm{H} 1$ diterima atau terdapat pengaruh yang signifikan antara Manajemen Laba Riil terhadap Nilai Perusahaan. 


\section{SIMPULAN}

Manajemen Laba yang dilakukan perusahaan dengan menggunakan metode perhitungan manajemen laba riil pada 34 perusahaan yang tergabung di Industri Manufaktur pada Bursa Efek Indonesia periode 2015-2017 berdasarkan hasil penelitian ini berpengaruh positif dan signifikan terhadap nilai perusahaan yang diproksikan dengan Rasio PBV dengan nilai pengaruh sebesar 15,6\%.

\section{DAFTAR PUSTAKA}

Adisetiawan, R., and Yunan Surono, 2016, Earning Management and Accounting Information Value: Impact and Relevance, Business, Management and Economics Research, 2(10), 170-179

Adisetiawan, R., 2011, Relevansi Nilai Informasi Akuntansi pada Indeks LQ45, Jurnal Akuntabilitas, 1(1), $119-126$

Ariyanto, A., Alhudhori, M., Sakinah, S., 2017, Pengaruh Return on Equity (ROE) dan Net Profit Margin (NPM) terhadap Laba Usaha pada Bank Milik Negara Selama Periode 2011-2015, EKSIS: Jurnal Ilmiah Ekonomi dan Bisnis, 8(1), 12-20

Cohen, D., \& Zarowin., P. 2010, Accrual Based And Real Earning Management Activities Around Seasoned Equity Offerings, Journal of accounting and Economics, 50(1), 2-19.

Gunny, k., 2005. What Are The Consequences Of Real Earnings Management?, Working Paper, Haas School of business, University of California, Berkeley.

Healy, Paul. M., James, M., Wahlen, 1999.A Review Of The Earnings Management Literature And Its Implications For StandartSetting. Accounting Horizon.

Li., C,. Tseng, Y., Q., Chen, T., K, 2016. Top Management Team Expertise And Corporate Real Earnings Management Activities Advances In Accounting. Incorporating Advances in International Accounting.

Zang, AY., 2012, Evidence on The Trade off Between Real Activities Manipulation and Accrual-basedBased Earning Management. The accounting Review, 87(2), 675-703. 